Richard Walsh, "A Modest Proposal for Christ-Figure Interpretations: Explicated with Two Test Cases," Relegere: Studies in Religion and Reception 3, no. I (2013): 79-97.
(c) BY-NC-ND This work is licensed under a Creative Commons Attribution Non-Commercial No Derivatives 3.o License.

Relegere: Studies in Religion and Reception is an independent, open-access academic journal dedicated to the promotion and dissemination of innovative research in reception history, broadly conceived, within and across religious traditions.

Www.relegere.org

ISSN I I 79-723 I 


\section{Richard Walsh}

\section{A Modest Proposal for Christ-Figure Interpretations}

\section{Explicated with Two Test Cases}

The covert theologizing in some Christ-figure analyses, along with the failure to give serious consideration to the films under discussion, has rendered the approach suspect to all but those sharing the analyses' theological presuppositions. Accordingly, many have called for moratoriums on Christ-figure interpretations. Nonetheless, more modest christ-figure analyses, which respect film genres and modern characterizations, might still gain a broader academic hearing. To further that case, this essay provides a christ-figure analysis of two films (Donnie Darko; The Wrestler), which "visually quote" or "footnote" two Jesus films (The Last Temptation of Christ; The Passion of the Christ), and then attempts to explicate what "christ" means in these films, rather than in a particular theological tradition. The intertextuality that these two film christs establish broadens the meaning of "christ" and may also reconfigure other, more traditional christs.

\footnotetext{
$\Lambda^{S}$ RELIGION and film studies have grown increasingly sophisticated, many scholars have called for a moratorium on the study of "Christ figures" in Richard Walsh is Professor of Religion at Methodist University.
} 
film. ${ }^{1}$ They do so in dismay at scholars and bloggers who see virtually every film hero(ine) as a Christ figure and in order to challenge academics to move beyond Christian biases and covert apologetics and to become more sophisticated in their analyses of film as film. Such appeals can hardly be ignored because there are many good reasons to fret about scholarly fascination with film Christ figures. ${ }^{2}$

For instance, the focus on Christ figures minimizes, if it does not overlook entirely, other more enlightening allusions. Thus, while one can read Neo in The Matrix ${ }^{3}$ as a Christ figure with some justification, that interpretation will miss elements that reading Neo as bodhisattva, Platonic philosopher, or Alice in Wonderland might better illumine. One can also read Jericho Cane in End of Days ${ }^{4}$ as a Christ figure, but that interpretation will obscure elements that reading Jericho Cane as the dying king of New Years' festivals or simply as the increasingly common martyr hero(ine) of film will unveil more easily. ${ }^{5}$

A focus on Christ figures also distorts the fact that Neo, Jericho, and others are first and foremost cinematic heroes. As The Matrix's Neo illustrates, filmmakers cadge together numerous traditions to create syncretic heroes in order to widen the appreciative market for their films. ${ }^{6}$ Thus, Buddhists,

${ }^{1}$ For a summary of critiques of Christ-figure analyses, see Christopher Deacy, "Reflections on the Uncritical Appropriation of Cinematic Christ-Figures: Holy Other or Wholly Inadequate?," Journal of Religion and Popular Culture I 3 (Summer 2006). In an attempt to exclude "outlandish" interpretations, scholars who do argue for Christ-figure analyses typically contend that some definable criteria must ground the interpretation. See Lloyd Baugh, Imaging the Divine: Jesus and Christ-Figures in Film. (Kansas City: Sheed \& Ward, I997), I09-I 2; Anton Karl Kozlovic, "The Structural Characteristics of the Cinematic Christ-Figure," Journal of Religion and Popular Culture 8 (Fall 2004); and Adele Reinhartz, "Jesus and Christ-Figures," in The Routledge Companion to Religion and Film, ed. John Lyden (London: Routledge, 2009), 43 I. Deacy prefers to search for a "two-way conversation" between theology and film, rather than specific Christ-figure correlations. This article's argument resembles Deacy's proposal, but it grounds its initial foray in two films that visually footnote Jesus films.

${ }^{2}$ I use the upper case where "the Christ" of Christian theology is in view and the lower case for cinematic christs and for my modest proposal.

${ }^{3}$ The Matrix, dir. Andy and Lana Wachowski, I 36 min. (Warner Bros, 1999).

${ }^{4}$ End of Days, dir. Peter Hyams, I 2 I min. (Beacon Communications, I 999).

${ }^{5}$ See Laura Copier, Preposterous Revelations: Visions of Apocalypse and Martyrdom in Hollywood Cinema 1980-200o (Sheffield: Sheffield Phoenix, 2012).

${ }^{6}$ For an argument that popular film is an "empty container" susceptible of almost any interpretation, see David Jasper, "On Systematizing the Unsystematic: A Response," in Explorations in Theology and Film: Movies and Meaning, ed. Clive Marsh and Gaye Ortiz (Oxford: Blackwell, I997), 235-44. 
Christians, gaming geeks, philosophers, and others can all relate to some piece of the mosaic that is Neo. Further, as other films and their characters are the primary fodder for the construction of film characters, cinematic heroes are invariably modern heroes, not those of some premodern religious tradition. Basting heroes with allusions to the Christ, then, is part of film's deification of the modern individual, and an interpretative focus on Christ figures runs the risk of turning from this modern context to ancient religious traditions far too quickly.

A focus on Christ figures also leads too easily to the global claim that particular films are Christ-figure films. The notion misprisions most films generically. Filmmakers routinely deny that their films are Christ-figure films even though religion academics argue that the same films are such. Filmmakers do not typically think of their films in theological terms and do not think of a Christ-figure genre of film. ${ }^{7}$ Thus, while religion scholars have illumined aspects of The Shawshank Redemption ${ }^{8}$ by reading it as a Christ-figure film, filmmakers will more likely think of it as a prison (escape) film. Even Jesus films are not really Christ-figure films in Hollywood parlance. Instead, they belong to other recognizable Hollywood categories. They are biblical epics, musicals, horror, and so forth. ${ }^{9}$

Finally, while it is a more religious than cinematic quibble, claims about Christ figures in film often use "Christ" quite loosely. Sometimes "Christ" means that a film hero(ine) appears in a scene that seems to allude to some

7 The concern here is not to establish the meaning of a film by appealing to a filmmaker's intention, but rather to acknowledge the different, non-theological context in which filmmakers work. Certainly, some filmmakers have theological aims, and some few films might best be described generically as Christ-figure films. Jesus of Montreal (dir. Denys Arcand, I I 8 min. (Centre National de la Cinématographie, 1989)), He Who Must Die (dir. Jules Dassin, I 22 min. (Indusfilms, I957)), etc., might be examples of such. In most cases, however, filmmakers and film critics would likely think of some film genre, even in these cases.

${ }^{8}$ The Shawshank Redemption, dir. Frank Darabont, I 42 min. (Castle Rock Entertainment, I994).

${ }^{9}$ See Jeffrey L. Staley and Richard Walsh, Jesus, the Gospels, and Cinematic Imagination: A Handbook to Jesus on DVD (Louisville: Westminster John Knox, 2007); or biopics in Adele Reinhartz, Jesus of Hollywood (New York: Oxford University Press, 2007), 3-40. In theological interpretations of Christ-figures, Jesus films could hardly be Christ-figure films, because that perspective envisions Jesus, even in cinematic form, as "the (theological, historical) original" that later (fictional) figures/characters imitate or reflect. If one thinks of messiahs in plural terms, however, Jesus' foundational nature vanishes. From that perspective, Jesus films might well be the cinematic example of Christ-figure films (although only those with religious interests would see them so). Such films do, after all, baste one (supposedly historical) character with Christian hagiography. 
gospel passage. Sometimes, it means that a film hero(ine) advocates nonviolent resistance. More commonly, it means that a figure is mysterious or supernatural in some sense. Most commonly, it means that a hero(ine) dies and that this death is redemptive for others. Clearly, "Christ" has such a breadth of meaning that almost any hero(ine) can be seen as Christlike in some way. ${ }^{10}$ But, if this is so, claims about Christ figures soon become rather trite; they lack enlightenment, interest, and heuristic potential for the analysis of particular films. ${ }^{11}$

Despite these problems, reasons exist for continuing Christ-figure analyses. First, scholars have done more interesting work with Christ figures than this critique has so far suggested. The work of Robert Detweiler, Theodore Ziolkowski, Anthony Swindell, and Zeba Crook on literary transformations of Jesus Christ ${ }^{12}$ and the work of Lloyd Baugh, Christopher Deacy, and Adele Reinhartz on Christ figures in film provide examples. ${ }^{13}$ Second, to ignore Christ figures may miss as much as an obsessive concentration on Christ figures does. Third, as filmmakers draw upon other films to create their own, they may sometimes turn to Jesus/Christ films as a source. The two test case

${ }^{10}$ Reinhartz observes, "Indeed, it may be said, with only slight exaggeration, that Jesus Christ, or someone who resembles him, is on view at every Cineplex in North America at any given moment" ("Jesus and Christ-Figures," 430). A claim about Christ-figuring in a particular film is then hardly enlightening and borders on the trite. See Clive Marsh, Cinema and Sentiment: Film's Challenge to Theology (Waynesboro: Paternoster Press, 2004), 48-5I; Deacy, "Uncritical Appropriation of Cinematic Christ-Figures."

${ }^{11} \mathrm{Or}$, as is argued here, one's interpretation needs to identify the christ in question as precisely as possible and needs to allow the film under review to have its say about what a christ is, rather than letting theological certainty dictate matters. In such christ-figure interpretations, the assumption about christs is plural, not singular or original. For a sense of the multiple meanings of "messiah," see the special issue of Postscripts: The Journal of Sacred Texts and Contemporary Worlds 3. no. 2-3 (2007), edited by Jay Twomey.

${ }^{12}$ Robert Detweiler, "Christ and the Christ Figure in American Fiction," The Christian Scholar 47, no. 2 (1964): I I I-24; Theodore Ziolkowski, Fictional Transfigurations of Jesus (Princeton: Princeton University Press, 1972); Anthony C. Swindell, Reworking the Bible: The Literary Reception of Fourteen Biblical Stories (Sheffield: Sheffield Phoenix Press, 2010), I76-203; and Zeba Crook, "Jesus Novels: Solving Problems with Fiction," in The Blackwell Companion to Jesus, ed. Delbert Burkett (Chichester: Blackwell, 20 I I), 504-I 8.

${ }^{13}$ Baugh, Imaging the Divine; Christopher Deacy, Screen Christologies: Redemption and the Medium of Film (Cardiff: University of Wales Press, 200I); Deacy, "Uncritical Appropriation of Cinematic Christ-Figures"; and Reinhartz, "Jesus and Christ-Figures." One might use, e.g., either Detweiler or Swindell's work as a basis to reflect on christ figures in film from a semiotic or literary/cinematic, rather than theological, perspective. Deacy is salutary for his call for a genuine conversation between film and theology ("Uncritical Appropriation of Cinematic Christ-Figures"). 
films discussed below clearly visually "quote" or "footnote" Jesus films. To ignore such footnoting or other allusions to Christ(ianity) in such films simply because one knows "bad" Christ-figure analyses seems to close down possible interpretations far too quickly. In fact, if one thinks of intertextuality in a postmodern sense, one cannot dogmatically exclude any allusions that an interpretation creates, even those that one does not like or find interesting.

Despite academics' persistent suspicions about (covert) theological agendas in Christ-figure analyses, it might then still be interesting or enlightening to propose modest christ-figure interpretations. One might even garner a hearing broader than those who happen to find the theological agenda of a particular interpretation convenient if one proceeds modestly enough. Such an approach would acknowledge that "christ-figure film" is not a cinematic genre and that alleged cinematic allusions to christ are at most only one component of a modern cinematic hero. More pointedly, a modest christ-figure analysis would not envision films simply as sites to do theology. Instead, a modest christ-figure analysis would assay a meaningful, interesting interpretation of the film in question. Accordingly, the film under review, not theology, would define the "christ" under discussion. Instead of explicating a particular tradition's theological Christ, such christ-figure analyses might reveal something about the popular understanding of christs and might subsequently cast some light on how the gospel christs are being read or might be read outside of their canonical and traditional ecclesial confines. ${ }^{14}$

This essay attempts to explicate such christ-figure analyses through a discussion of two film test cases: Donnie Darko ${ }^{15}$ and The Wrestler. ${ }^{16}$ These films visually quote or footnote specific Jesus films. While such obvious material connections with christ traditions may not be absolutely necessary for modest christ-figure analyses, the choice here of two films with such links attempts to take seriously the important critiques levied against Christian myopia in previous Christ-figure analyses. Not incidentally, these particular film christs are hardly those of any traditional theology. Their definitions of "christ" arise from their protagonists' stories and characterizations.

\footnotetext{
${ }^{14}$ This phrasing deliberately alludes to Larry Kreitzer's famous suggestion about "reversing the hermeneutical flow" (The New Testament in Fiction and Film: On Reversing the Hermeneutical Flow (Sheffield: Sheffield Academic Press, 1993)).

${ }^{15}$ Donnie Darko, dir. Richard Kelly, I I 3 min. (Pandora Cinema, 200I).

${ }^{16}$ The Wrestler, dir. Darren Aronofsky, I09 min. (Fox Searchlight Pictures, 2008).
} 


\section{Deadly Messianic Dreams: Donnie Darko and The Last Temptation}

Donnie Darko is a cult classic about a suicidal teenage schizophrenic. The frighteningly smart Donnie has problems. He has burnt a house down. He takes, and sometimes does not take, medications for his emotional problems. He has an expensive therapist. He sleepwalks. He quarrels with his family. And he has visions of Frank, an apocalyptic rabbit, who tells him that the world is going to end in twenty-eight days on Halloween.

Doubtful at first, Donnie eventually equates this scary rabbit with God/ fate, death, and his own desolating fear of loneliness. A mildly rebellious English teacher leads Donnie to Graham Greene's short story "The Destructors" and to the idea that destruction is creation. A nervous physics teacher points Donnie to The Philosophy of Time Travel by Roberta Sparrow, a.k.a. Grandma Death, which asserts that wormholes proceed from each person and determine that person's future path. Gretchen Ross, the new girl in town and Donnie's girlfriend, leads Donnie to the wish that one might travel back in time and replace bad stuff with beautiful images. Combined, this bricolage forms Donnie's apocalyptic destiny.

The film's climax occurs at Grandma Death's house as Donnie's timetable runs out. There, a brawl with bullies leaves Gretchen unconscious in the street. A young man, wearing a rabbit costume and named Frank, strikes and kills Gretchen with his car as he swerves to avoid Grandma Death, who is en route to her mailbox to retrieve a letter written by Donnie. Donnie, wearing a skeleton (death) costume, shoots and kills Frank.

In a surprising denouement, Donnie takes Gretchen to the mountain overlook where the film began. He has visions of wormholes in the sky, announces he is going home, and returns to his bedroom and to October 2 as the film rewinds. At the beginning of the film, Donnie miraculously escaped a freak accident when a jet engine fell into his room on October 2. Donnie was not there because he was sleepwalking to his first vision of Frank. Accordingly, Donnie has acted in the film as if he owes his life to Frank. On this new October 2, however, Donnie is in the room when the jet engine arrives and he dies smiling. His voiceover says he hopes he will have something to look forward to when the world ends, and the film's final music includes the repeated refrain, "dreams in which I'm dying are the best I've ever had." 17

${ }^{17}$ Film quotations are transcriptions from DVDs unless otherwise indicated. The comments in the text above refer to the theatrical version of Donnie Darko. In the director's 
Nothing in this recap demands that one see Donnie as a christ figure. Apocalyptic visions/destiny and notions of redemptive death are not unique to christ figures. The film's most obvious cinematic connection is with Harvey. ${ }^{18}$ I have, however, deliberately omitted the film's most important christfilm quotation or footnote, which occurs during Donnie and Gretchen's date at a Halloween Frightmare Doublefeature featuring The Evil Dead (Figure I). ${ }^{19}$ In that movie, a group of 20-somethings go to a wilderness cabin, find the Sumerian Book of the Dead in the cabin's basement, play a tape of an archeologist reading demon-resurrection incantations from it, and inadvertently raise demons which kill them all. ${ }^{20}$

While Donnie and Gretchen watch this film (one sees a shot of the station wagon arriving at the ill-fated cabin), Gretchen falls asleep and Frank appears to Donnie to give him an apocalyptic mission. Donnie is to follow a portal in the movie screen to a child pornographer's house and burn it down. When Donnie leaves Gretchen and the theater for his mission, however, he does not use the "portal." Instead, he leaves by the front entrance and pauses so that he stands framed under the movie marquee. There, one learns for the first time

cut, Roberta Sparrow's The Philosophy of Time Travel explains that the film's story transpires in a tangent universe (whose origin is not explained). The tangent universe is connected to the primary universe by a portal and contains an artifact from the primary universe- the jet engine. Unless the tangent universe is properly collapsed by the return of the artifact, the tangent universe's imminent end also threatens the primary universe. The living receiverDonnie - has the job of returning the artifact and is assisted and manipulated to do so by other characters - particularly Frank and Gretchen — who are already dead in the tangent universe, but time travel back to interact with Donnie. The director's cut makes Donnie more messianic, and functions vis-à-vis the theatrical version in a way comparable to the functioning of the canon or creeds vis-à-vis the gospels. Significantly, however, Donnie still remains a troubled soul and his authority remains unclear. Further, this Donnie may be a gnostic or Buddhist savior. In addition to the travel between worlds, see also Frank's various demands that Donnie "wake up" or "pay attention." Sparrow's The Philosophy of Time Travel is available in the special features' section of the theatrical DVD and ubiquitously online. The section on deleted and expanded scenes provides the flavor of the director's cut for those without other access to it. In the director's cut, the opening and closing bedroom scenes are in different universes: the opening is in the tangent universe and the closing is in the primary universe, which messianic Donnie saves by sending the artifact back to the primary universe and by dying.

${ }^{18}$ Harvey, dir. Henry Koster, I04 min. (Universal International Pictures, I950).

19 The Evil Dead, dir. Sam Raimi, 85 min. (Renaissance Pictures, I98 I).

${ }^{20}$ Roberta Sparrow's The Philosophy of Time Travel, as the director's cut makes unmistakably clear, seals Donnie's fate. Other than the demonic Frank, bookish destiny is the closest connection between The Evil Dead and Donnie Darko. The campers in The Evil Dead do, however, arrive at their cabin in a station wagon (a scene shown in Donnie Darko), and Donnie does drive Gretchen to their "new end" in a station wagon. 

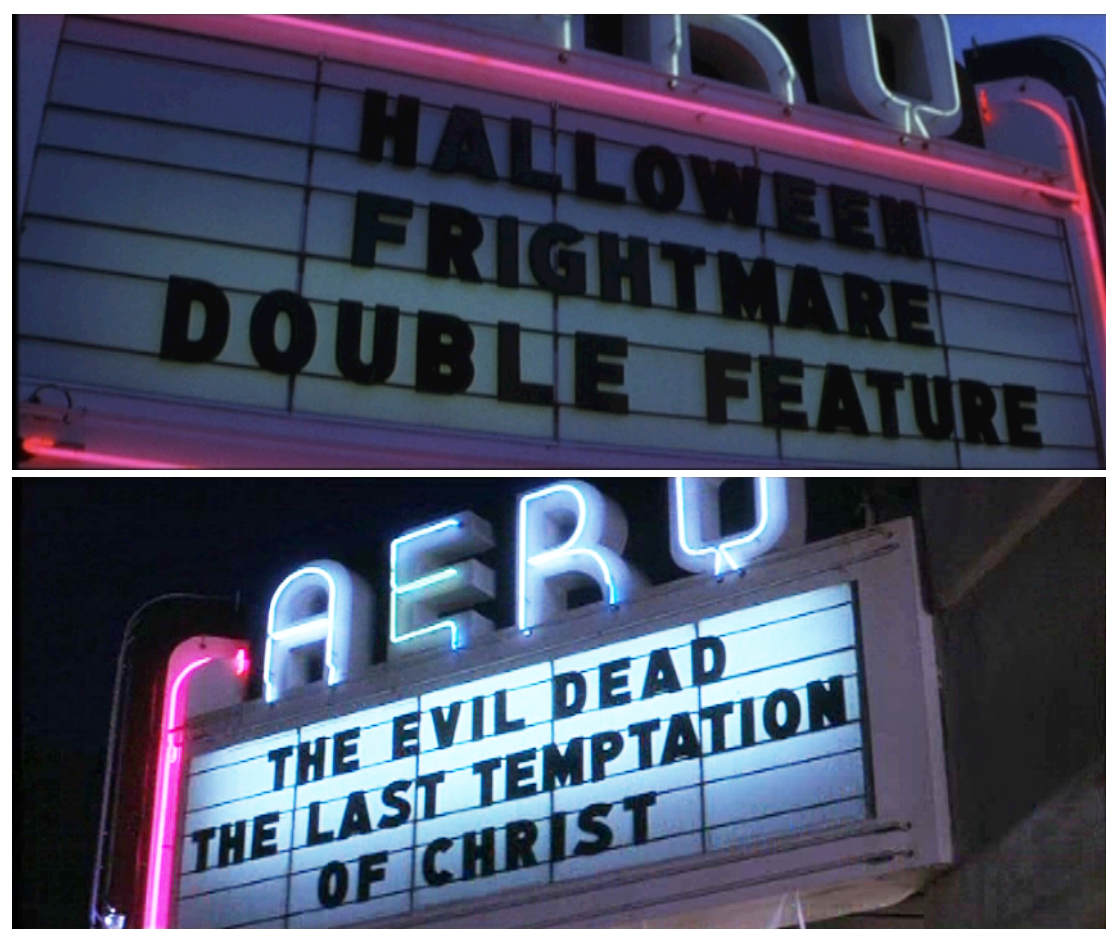

Figure I

that the second frightmare feature is The Last Temptation of Christ. ${ }^{21}$ When I first saw this scene in the theater, I was taken aback, but I still did not think of Donnie Darko as a christ figure-until I reached Donnie Darko's double ending.

After all, The Last Temptation of Christ also has a double (and fantastic) ending and features a visionary who chooses a messianic death. Dying on the cross, that Jesus has a detailed fantasy (styled a "temptation") of another life in which he sires children and eventually lies dying of old age as Jerusalem burns in the war of 66-73 CE. Judas intrudes into this fantasy, however, and shames Jesus into crawling back to the cross, begging God for his destiny, a messianic death. Like Donnie, this Jesus then dies smiling.

While Donnie Darko has clear connections with Harvey, E. T. The ExtraTerrestrial, The Evil Dead, Southland Tales, and a host of other films, the

${ }^{21}$ The Last Temptation of Christ, dir. Martin Scorsese, I64 min. (Universal Pictures, I988). 
marquee's quotation of The Last Temptation of Christ establishes a connection with that film as well. ${ }^{22}$ After reflection, other coincidences (the normal fodder of Christ-figure interpretations) soon appear. The heroes of both films first appear lying prone in solitary locales. ${ }^{23}$ Both are victims of haunting visions and troubling voices. Both are awake at the beginning of their film. After doubts, both eventually decide the voices they hear are divine and that the wish to escape these voices is futile. Both miraculously escape death near the beginning of their respective films: Donnie escapes the falling jet engine and Jesus the Zealot plot to assassinate him as a quisling. Ultimately, both return to this very death (the Zealot Judas helps Jesus to his cross in both the "reality" and fantasy sequences). Both have apocalyptic visions that lead them to acts of violence. Both take up the axe and talk of destroying houses (or temples). Both see themselves as the plaything of fate/destiny/God. Both press their destiny by going to dangerous places (either Grandma Death's house or the temple). Both ultimately choose a death that they alone see as meaningful and redemptive, and both heroes die with a smile.

Perhaps few of these coincidences matter, but the visual quotation of The Last Temptation of Christ by Donnie Darko's movie marquee haunts. Perhaps, it asks the viewer to compare the destinies of Donnie and the Jesus of The Last Temptation of Christ. Is their choice of death over life divine destiny or is it simply suicide? Christian interpretations of Jesus' death rigorously avoid configuring Jesus' death as a suicide, ${ }^{24}$ but Donnie Darko's connection with The Last Temptation of Christ charts different territory.

Donnie Darko clearly belongs to horror. Donnie Darko's marquee assigns The Last Temptation of Christ to that genre as well. Both films flirt with deus ex machina resolutions only to reject them or, rather, to replace them with death ex machina resolutions. ${ }^{25}$ That adaptation focuses on death as relentlessly as any horror film. But the arc of both Donnie Darko and The Last Temptation of Christ makes death the powerful means by which the world is saved-or, at least, so their heroes believe. The films' trajectories hallow death.

${ }^{22}$ E. T. The Extra-Terrestial, dir. Stephen Spielberg, I I 5 min. (Universal Pictures, I982); Southland Tales, dir. Richard Kelly, I 45 min. (Universal Pictures, 2006).

${ }^{23}$ The shot of a prone Jesus from above is rather rare in Jesus films.

${ }^{24}$ See Richard Walsh, Three Versions of Judas (London: Equinox, 2010), 5 I-84.

${ }^{25}$ The director's cut of Donnie Darko has more than one reference to a deus ex machina, including one by Donnie in the fateful road outside Grandma Death's house. Does the phrase refer to the artifact that must be returned to the primary universe to save the world? 
Despite the heroes' beliefs, their self-isolation renders both films journeys into narcissism. As both films end with the smiling death of the hero, deaths which have no clear significance for anyone else, both films are also journeys into solipsism. ${ }^{26}$ The end of Donnie Darko creates a loop with its beginning that one cannot easily escape, without explanations provided by DVD extras or by the director's cut. In the theatrical version, one seems entrapped in Donnie's nightmarish visions, in their configuring of the world. ${ }^{27}$ The Last Temptation of Christ is similarly entrapping. Its Jesus first describes his visionary world in an interior monologue, but the film gradually visualizes Jesus' wilderness visions. In the second of these scenes, Jesus talks with a wilderness prophet. Subsequently, Jesus and the audience learn that the prophet is already dead when this happens. Without knowing it, the audience has come to share Jesus' visionary world as if it were (the cinematic) reality. The grand finale operates similarly. Various techniques render the crucifixion an "interior," spiritual experience-an experience with Jesus—rather than an outsider's experience of an exterior, material reality. Eerie silences punctuate the scene. The audience hears Jesus' thoughts and heartbeat. The audience hears a mighty storm but sees blue skies. Then, in an eerie calm at the eye of the storm, Jesus faces the tempting young girl. Then the viewers leave the cross with Jesus and enter the fantasy. Any grip on previous cinematic reality is lost. Such visions are troubling. They leave one uncertain about reality and about the visionaries' identities. ${ }^{28}$

${ }^{26}$ The time traveling explanation makes the director's cut of Donnie Darko less solipsistic than the theatrical version. In fact, suicide, horror, narcissism, and solipsism are more evident in The Last Temptation of Christ than in even the theatrical version of Donnie Darko or, perhaps, they are simply more obvious in The Last Temptation of Christ after one sees that Hollywood Frightmare Double-feature marquee in Donnie Darko.

${ }^{27}$ MaryAnn Johanson suggests that both post-October 2 stories are psychotic fantasies; that there is no reality outside Donnie's mind after the first warning ("Choose Your Own Psychotic Breakdown,” October 26, 200I, http://www.flickfilosopher.com/flickfilos/archive/ o $4 \mathrm{q} /$ donniedarko.shtml). On the DVD cover, Donnie and Frank's faces morph into one another-suggesting that they are one character or that Frank is a voice in Donnie's headbefore one ever views the DVD. Despite Frank's status in the director's cut as one of the manipulated dead, trying to trap Donnie into returning the artifact, the frequent appearance of Frank's head in Donnie's pupil has some of the same aura.

${ }^{28}$ Kelly's intriguing, perplexing Southland Tales offers more hope for an escape from such apocalyptic nightmares. It does so through yet another configuration of "messiah," as a nonsuicidal pimp, who stands over against a suicidal, and far more traditional, christ figure. Discussion of this complex film would require more space than this article affords. See Lee Quinby, "Southland Tales, The Film of Revelation: Richard Kelly's Satire of American Apoc- 
If Donnie Darko is a christ figure, he is not one from any traditional theology. At least in the theatrical version of the film, Donnie seems instead what common parlance normally means by a "messiah," a dangerous, deadly, self-aggrandizing "nut." After all, apart from external sanction, messianic claims are always suspect. Donnie becomes credible only through the lens of the DVD extras or the director's cut. But, then, the Jesus of The Last Temptation of Christ also relies on external sanction, the hallowing force of Christian tradition. That he is the hero of a Jesus film alone ennobles him.

When The Last Temptation of Christ appears on Donnie Darko's marquee, something different transpires. The Christian tradition loses its definitive control. The connections now link this Jesus with the walking, scripted dead of The Evil Dead. Jesus becomes another horror victim. Jesus stands beside Donnie Darko - and other messianic claimants necessarily rejected by the singularity of the Christian tradition (unless, of course, one can configure them as a Christ-figure). He is a suicidal nut-job (as, not incidentally, the gospels depict their critics saying of their Jesuses). Conservative critics of The Last Temptation of Christ agree about this specific Jesus, but they do so in order to protect the uniqueness of their Christ. But, once one links this Jesus with Donnie Darko, and other suspicious figures, "nut job" becomes part of the meaning of "christ (messiah)" and even gospel Jesuses become less credible. After all, in what way are the gospels' Jesuses themselves messiahs or christs? Do such designations rely upon some characters murmuring deus ex machina or upon the directors' cuts? Do these Jesuses also begin to resemble victims of horror? ${ }^{29}$

\section{One-Trick Ponies: The Wrestler and The Passion of the Christ}

Donnie Darko is a darkly comic horror film. The Wrestler is a documentarylike view of its protagonist's destructive obsession with his career as a professional wrestler. The glory days of the I 980 os are long gone for Randy the Ram when the film opens. Once a major Madison Square Garden attraction, the Ram is now a small-time wrestler struggling to make rent in dingy makeshift

alypse," in Reel Revelations: Apocalypse and Film, ed. John Wallis and Lee Quinby (Sheffield: Sheffield Phoenix Press, 2010), 25-43.

${ }^{29}$ Albert Schweitzer's famous depiction of Jesus as an apocalyptic fanatic who threw himself upon the wheel of time, which rolled on, approximates such a Jesus. Is it a coincidence that both The Last Temptation of Christ and The Passion of the Christ have numerous features of cinematic horror? See Richard Walsh, "The Passion as Horror Film: St. Mel of the Cross," Journal of Religion and Popular Culture 20 (Fall 2008). 

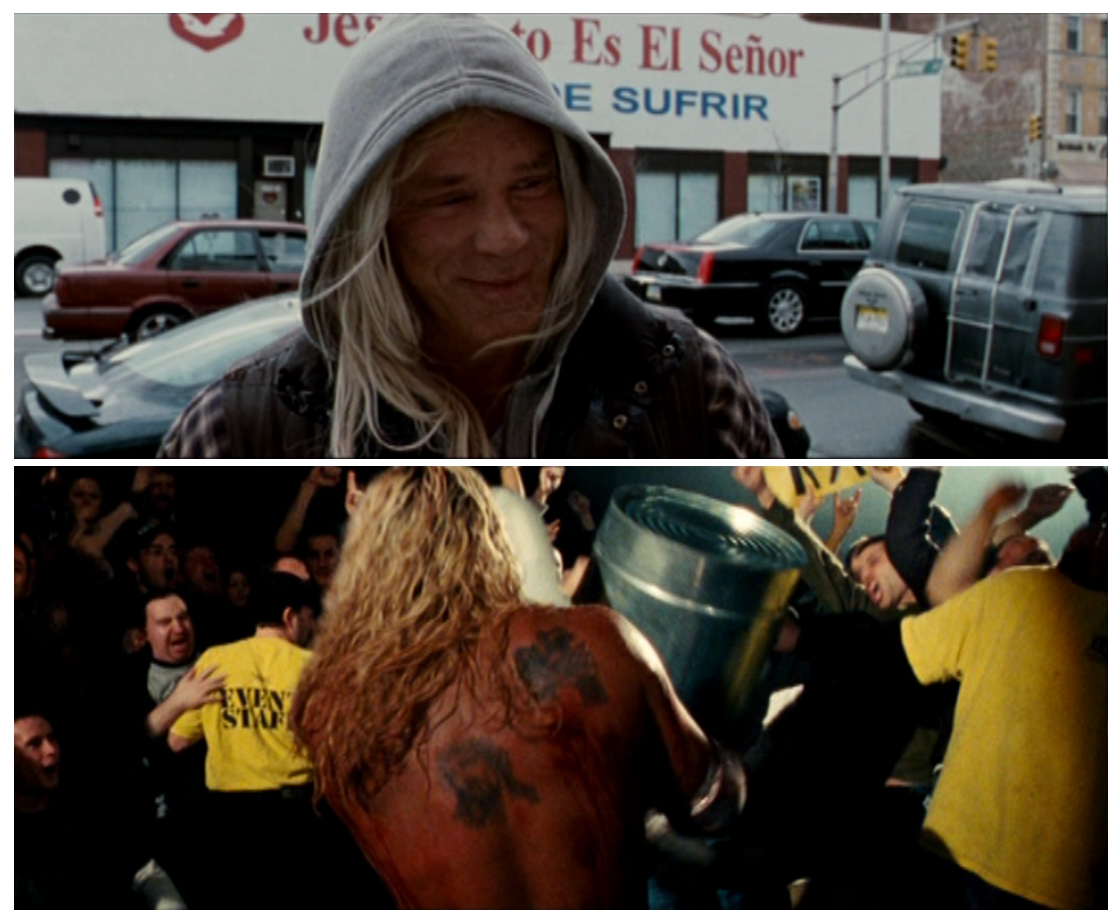

Figure 2

arenas. Accordingly, the primary cinematic connections for The Wrestler, other than Darren Aronofsky's other films about self-destructive obsessions, are various sports films, particularly those about athletes in decline.

Like Donnie Darko, however, The Wrestler also employs christ imagery; but where Donnie Darko is chary with such allusions, The Wrestler is profligate. On one occasion, the mise-en-scène places the Ram prominently under a billboard that declares Jesus Lord in Spanish. The similarity with Donnie Darko's marquee-scene is obvious. The fact that one often sees an actionfigure doll of the Ram, not the Virgin Mary or the Christ, mounted on the dash of the Ram's van (a Dodge Ram, of course) underlines the billboard's effect. Neither of these gestures, however, connects the Ram decisively with a christ. Matters are different with the film's repeated shots of a tattoo of Jesus' head crowned with thorns on the Ram's back (Figure 2). While still not yet a quotation, the tattoo echoes the quotation's effect concisely. 
The quotation or visual footnote itself occurs in a scene after a promoter offers the Ram an opportunity to recreate his I 980 os glory days in a twentieth anniversary rematch of his fight with the Ayatollah in the Garden. ${ }^{30}$ In triumph, Ram visits his favorite strip club, where he saves Cassidy, his favorite, but aging exotic dancer, from humiliation at the hands of college students. Afterwards, Ram makes up her lost tips by paying for a lap dance. The lap dance anoints Ram as a christ figure as the Ram talks about his glory days and his rematch as he flirts with making an honest woman of Cassidy. ${ }^{31}$

The Ram is still bleeding from a cut, self-inflicted in his last match in order to give the crowds the blood they pay to see. Seeing the blood, Cassidy talks about the pain and suffering the Ram endures to wrestle, and he proudly catalogues various injuries saying, "It hurts when you breathe, but, I mean, you hear the roar of crowd and you pull through her through, you know." Cassidy, then, turns theologian and film critic quoting, "He was pierced for our transgressions, he was crushed for our iniquities, the punishment that brought us peace was upon him, and by his wounds we were healed" (as she strokes his face and hair lovingly). When a confused Ram wonders what she is talking about, Cassidy explains, "It's The Passion of the Christ. You have the same hair. You never seen it? Dude, you gotta. It's amazing. They throw everything at him whips, arrows, rocks. They beat the living fuck out of him the whole two hours." Ram responds, "Tough dude." Cassidy says laughing, "Sacrificial ram."

As one laughs at the prescience of the "hair" comment, which succinctly states the most important characteristic of the Hollywood Jesus(es), and at Cassidy's ignorance of Isaiah (53:5), the fact that the quotation renders both the Ram and the Jesus of The Passion of the Christ ${ }^{32}$ rams/lambs beaten and abused for our (paid) entertainment and transforms both their bodies into spectacles may slide by unnoticed. ${ }^{33}$ The leitmotif formed by the repeated

${ }^{30}$ This trajectory parodies recent American history: the glory days of the I 980 os and the attempts of the Bush presidencies to recreate the glory of Reagan in various "rematches" in the Middle East.

${ }^{31}$ While it is beyond this article's scope, the scene also resembles Jesus' anointing, particularly the version in Luke 7:36-50. Cassidy thus resembles the Mary Magdalene of popular media and church tradition, but not of the gospels, which never name her a prostitute.

32 The Passion of the Christ, dir. Mel Gibson, I 27 min. (Icon Productions, 2004).

${ }^{33}$ Guy Debord describes the society of capitalist consumerism as a spectacle (Society of the Spectacle, trans. Ken Knabb (London: Rebel, I983)). The Ram's body makes him part of this capitalist spectacle as do the visualized sufferings of the protagonist of The Passion of the Christ. 
shots of the suffering-head-of-Jesus tattoo on the Ram's back, however, underlines this connection.

Further, the next wrestling scene shows the Ram, with the Jesus-head tattoo repeatedly visible on his back, pierced (by a staple gun) and suffering from a gaping wound in his side. In a more subtle connection to The Passion of the Christ, The Wrestler cuts repeatedly from the post-match medical attention being given to Ram back to the inflicting of Ram's multiple piercings and wounds in the match. ${ }^{34}$ The Passion of the Christ, of course, cuts from its crucifixion and its pierced Jesus back to Last Supper scenes. Both editing techniques focus attention ritualistically on the body destroyed "for us." In both cases, the audience becomes (wrestling) fans who have paid to see the blood. ${ }^{35}$

After the bout, the Ram collapses from a heart attack. When the Ram awakes in a hospital, his doctor tells him that he has had bypass surgery-is he pierced "for us" again? - and that he cannot continue wrestling. After he almost has another heart attack in training, the Ram chooses (normal) life. Unfortunately, like Donnie Darko and Scorsese's Jesus, he is just not very good at it. He tries to reestablish a relationship with his daughter and fails. He tries to lure Cassidy into a relationship and fails. He tries to be satisfied with an average job, working the supermarket meat counter, and fails. As he says to his daughter in words that seem beyond his acumen, he is just "an old broken down piece of meat."

His job at the meat counter shows his limitations clearly. Going to work, he objects to the nametag that identifies him as Robin, his given name. He wants to be special, as his nerdy, tyrannical manager observes. He wants to be the anointed Ram. As he walks into work, adjusting his hairnet, the camera work and music suggest a gladiator or wrestler entering the arena. That is no longer Ram's world, however, and when a customer recognizes him as the Ram, the Ram loses control. He cannot be average Robin when the sacrificial Ram beckons. Treating himself like "meat," he thrusts his hand into the meat slicer, quits his job, and returns to wrestling-in an even more degraded state than before-and later to the rematch with the Ayatollah (to the musical accompaniment of "Balls to the Wall").

${ }^{34}$ The film features the slapping of the Ram, the spraying of aerosol in his face, multiple piercings with a staple gun, whippings with barb wire, and piercings with shattered glass.

${ }^{35}$ See Richard Walsh, "Wrestling with The Passion of the Christ: At the Movies with Roland Barthes and Mel Gibson," Bible and Critical Theory I, no. 2 (2005). 
Like Donnie Darko and the Jesuses of both The Last Temptation of Christ and The Passion of the Christ, the Ram chooses death. At least, he returns to wrestling, wearing a fleece vest, and to the crowds whose adulation he needs, as he admits in a speech to the crowd before his final match with the Ayatollah:

I just want to say to you all tonight I'm very grateful to be here. A lot of people told me that I'd never wrestle again and that's all I do. You know, if you live hard and play hard and you burn the candle at both ends, you pay the price for it. You know in this life you can lose everything you love, everything that loves you. Now I don't hear as good as I used to and I forget stuff and I ain't as pretty as I used to be, but god damn it I'm still standing here and I'm The Ram. As time goes by, as time goes by, they say "he's washed up," "he's finished," "he's a loser," "he's all through." You know what? The only one that's going to tell me when I'm through doing my thing is you people here. You people here. You people here are the ones worth bringing it for because you're my family. I love all of you.

In the ensuing match or ritualistic sacrifice, he repeatedly grasps his chest in pain. ${ }^{36}$ A heart attack seems imminent, and both his opponent and the referee try to stop the match repeatedly. The Ram persists, however, and in the final scene he mounts the ropes for his trademark move, the Ramjet, in which he flings himself into the air at his opponent. When the Ram leaps, the screen goes black. While one does not actually see his death, it seems predetermined by his obsession. Perhaps it does not matter. Alive or dead, the Ram has given himself "for us," for our entertainment. The music that plays as the credit rolls, "One Trick Pony," succinctly tells the tale.

Obsession also led to the protagonists' choices of death in Donnie Darko, The Last Temptation of Christ, and The Passion of the Christ. All are, indeed, one-trick ponies. Their messianic fantasies will not allow them to choose (a normal) life. Instead, they drive toward deaths that render them special. If Donnie Darko and The Last Temptation of Christ focus on the psychological sufferings of their christs, The Wrestler and The Passion of the Christ present their christs as bodily spectacles. The Ram and Gibson's Jesus die

${ }^{36}$ Before the match, the Ram kneels in prayer in his dressing room and crosses himself. The effect is similar to that of the Gethsemane scene in The Passion of the Christ. 


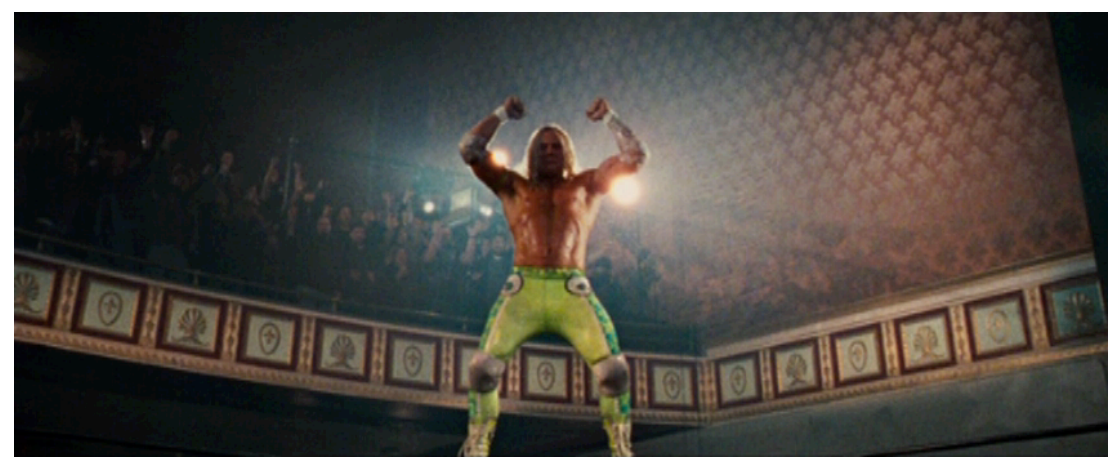

Figure 3

(unsmilingly) in agony. These two films and these protagonists have tattooed "messiah" on their bloody bodies. ${ }^{37}$ Both the Ram and Gibson's Jesus are broken-down meat destroyed and displayed "for us." Their spectacles entertain, pandering to our bloodlust and to our narcissistic desires. They do not atone.

If the Ram becomes a christ figure through The Wrestler's quotation of The Passion of the Christ, then the Jesus of the latter film also becomes a Ram figure or an Aronofsky character. While Aronofsky's next film, Black Swan, ${ }^{38}$ does not bathe its protagonist Nina in christ allusions, it does further flesh out Aronofsky's typically tragic obsessive. Nina's pursuit of her obsession fractures her reality, intertwining her fantasies confusedly with reality. Like Ram, she comes to a tragic end through her obsessions (here a pursuit of perfection) or through her desire for public acclaim. She even has her own "Ramjet." When The Wrestler links such characters to the Jesus of Gibson's film, what stops the links from including the gospels' Jesuses? Are they also Aronofsky characters? At minimum, they, too, are obsessive, scripted figures.

${ }^{37}$ Compare the fate of the Officer in Kafka's "In the Penal Colony."

${ }^{38}$ Black Swan, dir. Darren Aronofsky, 108 min. (Fox Searchlight Pictures, 2010). 


\section{A Modest Proposal}

These film heroes are anti-heroic. ${ }^{39}$ More accurately, Donnie Darko and The Wrestler's citations of The Last Temptation of Christ and of The Passion of the Christ render all these cinematic christs un-heroic. The films explore the dangerous fantasies of their protagonists' messianic desires. When the films christen their protagonists, they are not exalting them. Their semiotics depend less upon ecclesial traditions and more on popular culture where "messiah" often signifies destructive, obsessive fanatics, and where, since The Passion of the Christ, it has come increasingly to mean suicidal "splatter" victim. These films transform these protagonists into marquees warning their audiences of the dangers of christs or the perils of obsession, messianic desires, apocalyptic fantasies, and voyeuristic violence.

These christs are not antichrists. ${ }^{40}$ They do not deliberately oppose the noble, divine Christ of Christian tradition. At least, Donnie Darko and The Wrestler do not quote the gospels or the creeds. Like The Wrestler's Cassidy, it is not clear that they know scripture. ${ }^{41}$ They interact instead with other films and with popular messianic discourse. Nonetheless, they do create christs who undo theology's distinctive, singular "the Christ." Their protagonists are un-christs (or christs). They undo messianic attributions, calling attention to the semiotics of christ figuring.

Previous films have explored the crowd's role in making messiahs (for example, Jesus Christ Superstar, ${ }^{42}$ Being There, ${ }^{43}$ and Monty Python's Life of Brian). ${ }^{44}$ Donnie Darko, The Last Temptation of Christ, and The Wrestler home in on the protagonist's role in this process. Donnie Darko and Scorsese's Jesus tremble on the edge of insanity and finally name their troubled, divided imaginations destiny/God in order to find their own personal salvation. The Wrestler focuses instead on the Ram's deadly, obsessive desire for adulation, for the roar of the crowd for him, and for being special. In this process, all of these protagonists choose spectacular deaths, rather than ordinary lives.

39 The Passion of the Christ does, however, employ action-hero conventions. See Walsh, "The Passion as Horror Film."

${ }^{40}$ One could, of course, use the New Testament references to "antichrist" (I John 2:I 8, 22; 4:3; 2 John 7) to argue that any use of "christ" that does not denote Jesus makes one part of the antichrists.

${ }^{41}$ Southland Tales is another matter.

${ }^{42}$ Jesus Christ Superstar, dir. Norman Jewison, I08 min. (Universal Pictures, 1973).

${ }^{43}$ Being There, dir. Hal Ashby, I 30 min. (Warner Home Video, I 979).

${ }^{44}$ Monty Python's Life of Brian, dir. Terry Jones, 94 min. (HandMade Films, I979) 
As these films interrogate messianic semiotics, their signifying acids leak beyond the boundaries of popular culture and raise serious questions about obsessive fanatics and their scripts generally. They call into question the very notion of the heroic, particularly in its messianic version. Is it-even in its gospel deployments-inherently suicidal? Is it mere spectacle? Is it mere entertainment? Is it a sacrifice to bloodlust? Donnie Darko and The Wrestler do not follow these questions into (ecclesial) Christian discourse, but their viewers (particularly, if they are religion scholars) may.

Alongside these cinematic christs, the gospels' protagonists also become suspect. The "Christ" does not adhere well to the Jesuses of the gospels. ${ }^{45}$ The shrill loudness of the gospels on the point, the infamous device of the messianic secret, and the disciples' legendary failure to understand Jesus (as the Christ) all testify to this point. Even the resurrected Jesus is not clearly the Christ - the disciples think him a stranger, a gardener, or simply doubt altogether.

Perhaps Cassidy is not as biblically ignorant as one might presume. Perhaps, it is all about the hair. More accurately, it is all about the aura, the gloss, the comment, the chrism-the semiotics. In the light of cinematic transformations of christ, it becomes evident that the various gospels are themselves already deforming, forming, and defining "christ/messiah." Further, the cinematic connections potentially portray the gospels' various Jesuses as troubled visionaries, tortured souls obsessed with messianic destiny, fractured selves trying to write "christ" with and on their own abused bodies. The gospels' triumphs become desires for the crowd's adulation. They, and the passions that follow, become so many Ramjets. Like Donnie and the Ram, the gospels' Jesuses choose death, as their passion predictions and their garden prayers indicate.

Only religion scholars read films and texts so. At least, it is unlikely that the filmmakers of Donnie Darko and The Wrestler would characterize them as christ-figure films. ${ }^{46}$ They would be far more likely to speak generically of them as horror or sports films. The essences of these modern protagonists

${ }^{45}$ See Richard G. Walsh, "Three Versions of Judas Jesus," in Those Outside: Noncanonical Readings of the Canonical Gospels (New York: T \& T Clark, 2005); George Aichele, "Unchrist," Postscripts: The Journal of Sacred Texts and Contemporary Worlds 3, nos. 2-3 (2007): I 86-200.

${ }^{46}$ This observation does not mean that the director's (author's) intention is the final interpretation. (For that matter, the director's cut of Donnie Darko is not the final word. It is an interpretation of the theatrical version). The observation simply calls attention to the typically non-theological character of cinematic genres and marketing. 
lie respectively in teenage psychosis and suicide and in the obsessive desire for adulation. These foci, not the films' specific quotations of Jesus Christ films, give their characters their identities. The films do, however, quote Jesus Christ films as they characterize their protagonists. Accordingly, this article has tried to tease out these films' use of christ as a modest proposal on behalf of further attempts at christ-figure analyses as meaningful interpretations of the films in question.

Such forays should recognize the syncretic, cinematic, and modern character of cinematic heroes, respect the genre of the films under review, and seek to learn what "christ" means in the films' own intertextual play. These cinematic christs pluralize (or deform and reform) the meaning of "christ." Read with Donnie Darko and The Wrestler, "christ" means "nut job," "obsessive," and "spectacle of pain" as, or more easily, than it does "son of God," "savior," and so forth. Read with such christ figuring, the Christian gospels themselves become highly susceptible to similarly suspicious interpretations, rather than bulwarks against them, and they, too, clearly participate in christ figuring - the deforming and reforming of "christ." 